\title{
LPI \& COVID-19 RESTRICTIONS WITHIN BELT AND ROAD INITIATIVE IMPLEMENTATION
}

\section{ОБМЕЖЕННЯ ВІДНОСНО IHДЕКСУ LPI TA ПАНДЕМІЇ COVID-19 В РАМКАХ ВПРОВАДЖЕННЯ ІНІЦІАТИВИ НОВОГО ШОВКОВОГО ШЛЯХУ}

UDC 330.3

DOI: https://doi.org/10.32843/infrastruct59-1

\author{
Sylwia Nycz-Wojtan \\ Mgr., Ph.D Student \\ Vistula University \\ Warsaw, Poland \\ Fihun Nazar \\ $\mathrm{PhD}$, Associate Professor, \\ Department of Marketing and Logistics \\ Lviv Polytechnic National University
}

\begin{abstract}
The article considers the peculiarities of the BRI project development and changes in its implementation policy taking into account the COVID-19 pandemic and the corresponding quarantine restrictions. The role of logistics infrastructure and indicators that provides the level of its development in certain countries in the process of BRI project implementation are highlighted. The analysis of predictions regarding the level of impact of infrastructural changes on the level of employment, welfare and economy of the territories where the BRI project will be implemented has been carried out. The key elements of bottlenecks in the railway connection between the EU and China are highlighted. The main factors that impair the efficiency of railway customs have been identified, which includes: technological and qualitative nature. It is suggested to use a combination of $\mathrm{GCl}$ (Global Connectedness Index), LPI (Logistics Performance Index) and AEMLI (Agility Emerging Markets Logistics Index) to establish the level of logistics infrastructure of a particular country. The allocation of key infrastructure performance indicators in general and logistics indicators in particular will take into account the potential risks of project implementation, reduce non-strategic investments, increase the investments rate of return on the project, provide a greater effect of scale.

Key words: Belt and Road Initiative, BRI project, logistics, infrastructure projects, Covid-19, LPI, logistics efficiency.
\end{abstract}

B статье рассмотрены особенности развития BRI проекта и изменения в политике его реализации учитывая пандемию
COVID-19 и соответствующие карантинные ограничения. Освещена роль логисти ческой инсрраструктуры и показателей, которые указывают на уровень ее развития в определенных странах в процессе реализации BRI проекта. Осуществлен анализ прогнозов относительно влияния инсраструктурных преобразований на уровень занятости, благосостояние и экономику территорий, где будет внедряться проект BRI. Выделены ключевые элементы узких мест в железнодорожном сообщении стран EC и Китая. Идентифрицировано основные фракторы, ухудшающие эфрфективность работы железнодорожных таможен, к которым были отнесены: технологического и качественного характера. Предложено использовать комбинацию $\mathrm{GCl}$ (Индекс глобальной взаимосвязи), LPI (Индекс эфффрективности логистики) и AEMLI (Индекс логистики развивающихся рынков) для установления уровня логистической инфраструктуры конкретной страны. Выделение ключевых инсраструктурных показателей работы в челом и логистических показателей в частности позволит учесть потенциальные риски реализации проекта, уменьшить объемы не стратегических инвестиций, увеличить скорость окупаемости проекта, обеспечить более значительный эсрфрект масштаба.

Ключевые слова: Инициатива Нового Шелкового Пути, проект BRI, логистика, инсраструктурные проекты, Covid-19, LPI, логистическая эфрфективность.

У статті розглянуто особливості розвитку BRI проекту та зміни у політиці його реалізації враховуючи пандемію COVID-19 та відповідні карантинні обмеження. Висвітлено роль логістичної інфрраструктури та показників, які вказують на рівень ї̈ розвитку у певних країнах у процесі реалізації BRI проекту. Окреслено ключові міжнародні транспортні коридори за якими планується організовуватись товарообіг між Китаєм та Європою. Здійснено аналіз прогнозів щодо впливу індрраструктурних перетворень на рівень зайнятості, добробут та економіку територій, де впроваджуватиметься проект BRI. Виокремлено ключові елементи вузьких місць у залізничному сполученні країн ЄС та Китаю. Ідентифріковано основні фрактори, які погіршують ефрективність роботи залізничних митниць, до яких було віднесено: технологічного та якісного характеру. До технологічних фракторів віднесено: відсутність сучасних залізничних хабів, які б виконували фуункції перевірки, сортування, перевантаження товарів; відсутність гармонізації процесів митного оформлення; наявність швидких механізмів зміни ширини колійної бази потягів; наявність технічного устаткування для опрацювання усіх типів товарів; інструменти забезпечення безпеки кордонів; можливості для перевантаження, забезпечення карантину для товару, зміни контейнерів тощо. До фракторів якісного характеру віднесено: відсутність достатнього резерву персоналу у випадку збільшення обсягів товарообороту; кваліфрікація персоналу; якість обслуговування та механізми контролю якості надання послуг. Запропоновано використовувати комбінацію GCl (Індекс глобального взаємозв'язку), LPI (Iндекс есрективності логістики) та AEMLI (Індекс логістики ринків, що розвиваються) для встановлення рівня логістичної інфрраструктури конкретної країни (потенційного партнера у процесі впровадження BRI проекту). Виділення ключових інсрраструктурних показників роботи загалом та логістичних показників зокрема дозволить врахувати потенційні ризики впровадження проекту, зменшити обсяги не стратегічних інвестицій, збільшити швидкість окупності проекту, забезпечити більш значний ефеект масштабу.

Ключові слова: Ініціатива Нового Шовкового Шляху, проект BRI, логістика, інфрраструктурні проекти, Covid-19, LPI, логістична есрективність.

Formulation of the problem. Globalization processes have undergone significant adjustments due to the spread of the COVID-19 pandemic. One of the most ambitious projects in the world - the New Silk Road initiated by China has been significantly changed. After all, travel restrictions, quarantine, the 
vaccination process, and related new rules for the movement of people have changed the expectations of major project stakeholders, introduced a significant amount of uncertainty, especially for large-scale projects, and delayed the timeline for most projects already underway. Countries that have been active in promoting the Silk Road have become more financially restrained due to financial uncertainty, disrupted supply chains and the frequent lack of materials for active capital investment in infrastructure. All of the above indicates that BRI is in the process of concentrating on medium and small infrastructure transformations, and significant projects have been postponed to more stable economic periods. Nevertheless, COVID-19 and the general logistics situation demonstrate the importance of infrastructure and its role in ensuring further economic growth, even in the face of certain administrative constraints caused by the spread of COVID-19. With this in mind, it is important to investigate the extent to which the constraints caused by COVID-19 affect the implementation of the Belt and Road Initiative, given the efficiency of the existing logistics infrastructure of the countries covered by the planned corridors.

Analysis of recent research and publications. Many scholars focus on the implementation of the New Silk Road, the logistical challenges to infrastructure integration, and an analysis of the development potential of the BRI project. In particular, Taranyuk L.M. in [1] explores the logistical potential of the BRI project for Ukraine and Central Europe. Hanusik $A$. [2] highlights the benefits of the BRI project railway infrastructure development for the development of Poland and the logistical features of the northern route. The impact of logistics development on China's international trade in retrospect of the regions and the New Silk Road project is assessed in Wei Ma [3]. The New Silk Road creates significant competitive opportunities for the regions and increases their investment potential. With this in mind, Gniedziejko J. [4] evaluates the contribution of regional logistics solutions to the efficiency and viability of the EU and China's connected markets functioning. Innovation in logistics and supply chain development is a key element of Hing Kai Chan's research [5]. Despite the logistical potential of BRI investment solutions, other industries benefit as well. In particular, due to the effective connection of remote regions of the world, opportunities are created to strengthen the role of sectoral specialization of countries. Thus, the work of Carlucci F. [6] argues the role of logistics in the promotion of the Italian agricultural industry through the implementation of the BRI project, which becomes a prerequisite for the effect of investment synergy.

Problem Statement. The purpose of this study is to identify the impact of the state of logistics infrastructure and administrative restrictions to the material and human flows in quarantine caused by the COVID-19 pandemic during the implementation of the BRI project.

Presentation of the main research material. The Belt and Road Initiative (BRI) was announced by Chinese President Xi Jinping in 2013. During this period, a significant number of projects were launched aimed at expanding the infrastructure capacity of countries through which key routes for the transportation of goods from China to EU markets will pass. Under this initiative, six overland economic corridors are planned, which are schematically highlighted in Fig. 1, and several maritime routes are formed, mainly to North and South America, as well as for European consumers, as an alternative to overland transport in terms of price, volume, delivery time, etc. One of the main goals of the Belt and Road Initiative is to increase China's trade opportunities with key world markets. The motivation for development in this direction is, primarily, the presence of key logistical problems in the process of effective promotion of Chinese goods in the markets of Europe, Asia and the United States. The availability of technology, specialists, production capabilities and available end products are devalued when there are problems with delivery, in particular: its cost, cargo security, its traceability, delivery time, restrictions on the volume of goods allowed by customs regulations, difficulties with the return of cargo and the resolution of disputes between the consumer and the seller, etc. Thus, the expansion of logistics capabilities will improve the availability of goods made in China in most countries in Europe, Asia, North and South America.

The analysis of trends in BRI projects, especially during the COVID-19 pandemic, highlights the importance of rail transport as a key element in the sustainable development of this project. There are several reasons for this. First of all, neither sea transport with its relatively low speed of delivery, nor air transport with its high cost of delivering a unit of cargo can compare with the capabilities of rail transport. From a psychological point of view, if there are three options for the delivery of goods, the consumer will usually choose the so-called "middle" - the option that will not be the fastest or the most expensive, while providing the best offers in terms of cargo safety. Analyzing the potential for the development of railroads between China and the $\mathrm{EU}$, it can be noted that with existing infrastructure solutions and technology - the speed of cargo delivery by rail can increase by at least $12 \%$, which is almost impossible to achieve using sea or air transport. This optimization of the goods delivery speed is possible due to the improvement of customs inspection and registration of goods when crossing state borders. It should also be noted that the cost of shipping goods by rail is about $80 \%$ lower than the same delivery by air, and only half as slow as shipping by sea. However, it should be recalled that in the case of the maritime 


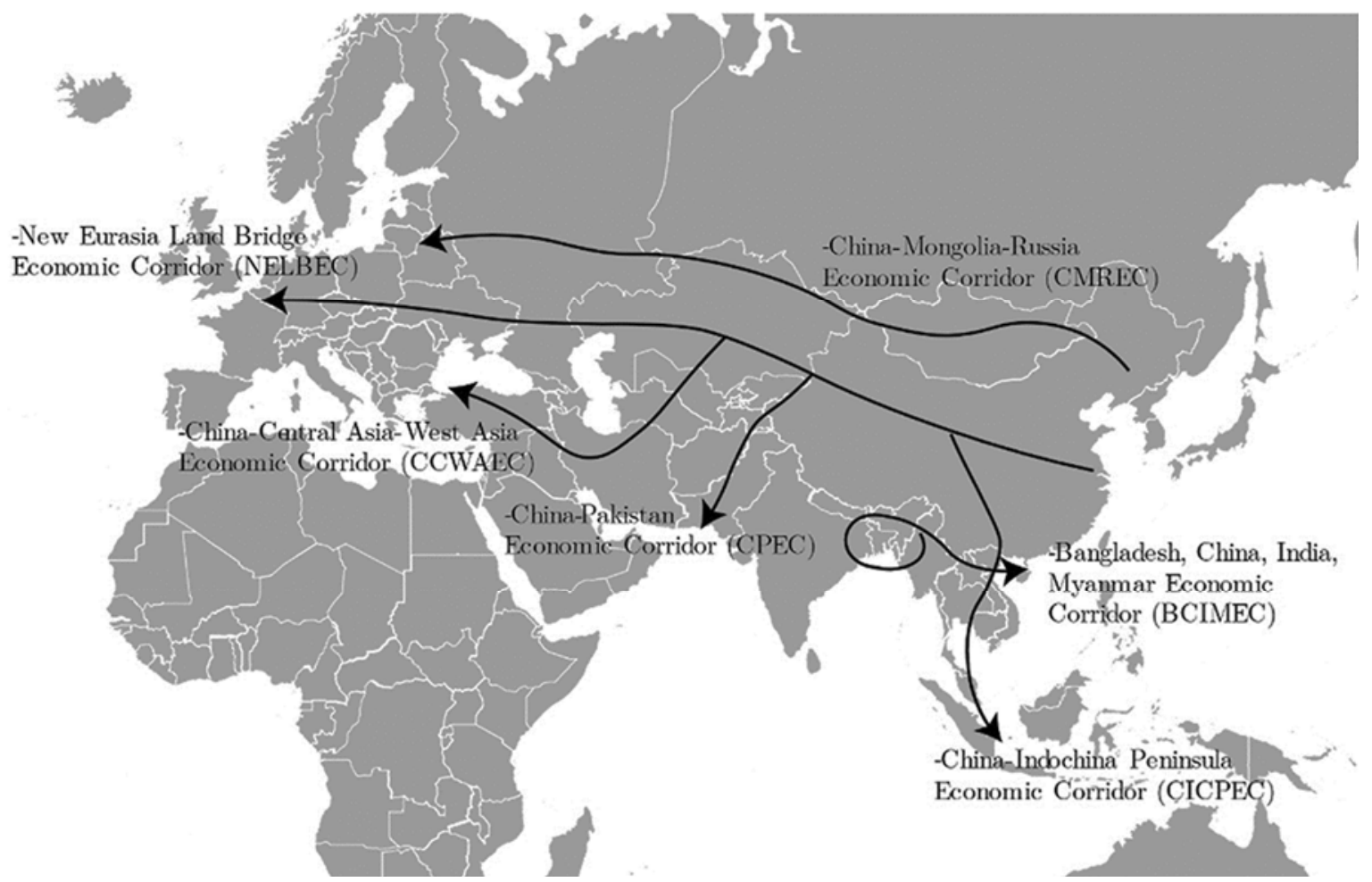

Figure 1. Six corridors and MSR route

Source: [7]

format of delivery of goods sometimes there are risks, including the presence of bottlenecks in the form of channels, the blockage of which (the example of the blockage of the Suez Canal in March 2021) leads to a collapse in world trade. Covid-19, unstable weather conditions, and restrictions on seaport operations between 2020 and 2021 have greatly increased the role of rail transport in ensuring uninterrupted trade between countries. Even during the pandemic, the level of rail transport remained a more or less stable mechanism for material flows. Before the pandemic and the implementation of the BRI project, there were projections of railroad speeds, branching railroad infrastructure, and improved transshipment centers [7]. However, analyzing the volume of improvement of railway transportation, its turnover and the number of operators in the international market - the projections set for 2027 will be achieved at least 5 years faster. At the same time, this shift will be achieved not only by increased trade, but also by lower rates of growth in sea and air freight shipments.

Improving rail transport is one of the key factors in the growth of its popularity. An important step in optimization is the establishment of a transparent exchange of information between all participants in the logistics chain. This will ensure the successful development of the railway service and avoid delays associated with the approval of documents. The development of rail service within the BRI will achieve a multiplicative effect. Infrastructure improvement allows to reach the increase of the economic attractiveness of certain regions, which in turn will provide (according to the prediction of World Bank Group) the growth of world trade by $3-10 \%$ in the nearest future. In addition to increased trade, the wellbeing of a large number of economically depressed regions will increase, since the land routes of the New Silk Road pass through countries with low well-being and high levels of migration. According to various estimates, the development of rail infrastructure into a single route will improve the financial situation and small businesses of more than 7.6 million people living in nearby regions.

In the process of improving the railway infrastructure, it is necessary to clearly recognize its small capacity for flexibility and the difficulty of changing routes associated with the disruption of the integrity of a single element of the logistics chain. The specifics of rail transportation is that with the increasing number of shipments, there are also a significant number of requirements for the strength of the logistics system, as well as the capacity at a significant number of hubs. Usually they can be expanded by $20-30 \%$, but expanding bottlenecks by more than $50 \%$ without significant investment is usually not possible. Harmonization of railway logistics chains is also a major limiting factor in the BRI implementation process. Various widths of railroads, differentiation of transportation requirements in different countries, cargo inspection and clearance processes at customs are important tasks and some of the most critical when implementing BRI. Given 
that the goods undergo several customs inspections during transportation by rail from China to Europe, customs, its openness, speed of cargo handling, transparency and the absence of corruption are some of the most important factors in improving the BRI project's land logistics chain. Key rail border control points are highlighted in Figure 2.

The main factors that impair the efficiency of railway customs include:

\section{- Technological nature:}

1. Lack of modern railway hubs that would perform the functions of inspection, sorting, and transshipment of goods.

2. Lack of harmonization of customs clearance processes.

3. Availability of fast mechanisms to change the width of the railway gauge.

4. Presence of technical equipment for processing all types of goods.

5. Border security tools.

6. Opportunities for transshipment, goods quarantine, containers change, etc.

- Qualitative nature:

1. Lack of sufficient personnel reserve in case of increased staff turnover.

2. Staff qualifications.

3. Quality of services and mechanisms to control its effectiveness.

Thus, the BRI project in the framework of the development of railway connections between China and Europe should focus not only on the infrastructure, but also to take measures to standardize the requirements for customs procedures throughout the distance of the New Silk Road. Improvements in this area will help boost the image of the countries participating in the New Silk Road project, as their score in the LPI (Logistics Performance Index) will also become more competitive, and reduce bottlenecks in the logistics flow.

One of the most important indicators in the process of effective implementation of the BRI project is the identification of bottlenecks, because the bottlenecks in the logistics chain are indicators of the performance of the entire system. They can provide an answer to where infrastructure should be developed in the future, where there are potential supply delays, and how to reduce their total number throughout the logistics chain. Border control points are usually bottlenecks in global supply chains. Strategically, answers to these questions will improve the speed, quality, flexibility, and ultimately the sustainability of rail freight shipments from China to the EU.

The development of logistics infrastructure related to the implementation of the BRI project has undergone significant changes under COVID-19, quarantine restrictions, and changes in trade processes due to changes in demand patterns in all markets between 2020 and 2021. One of the key changes in the development of railway infrastructure has been an increased focus on small and mediumsized projects. The main reason for this is a level of uncertainty. Significant investments have been cancelled or suspended. During the pandemic, the problem of container shortages on rail transport arose (in some places there is an oversupply of empty containers, while in others, on the contrary, there is a significant shortage). Despite volatile markets, rail transport showed positive investment dynamics during the pandemic (in contrast to air transport - a significant number of airports reduced the reception of

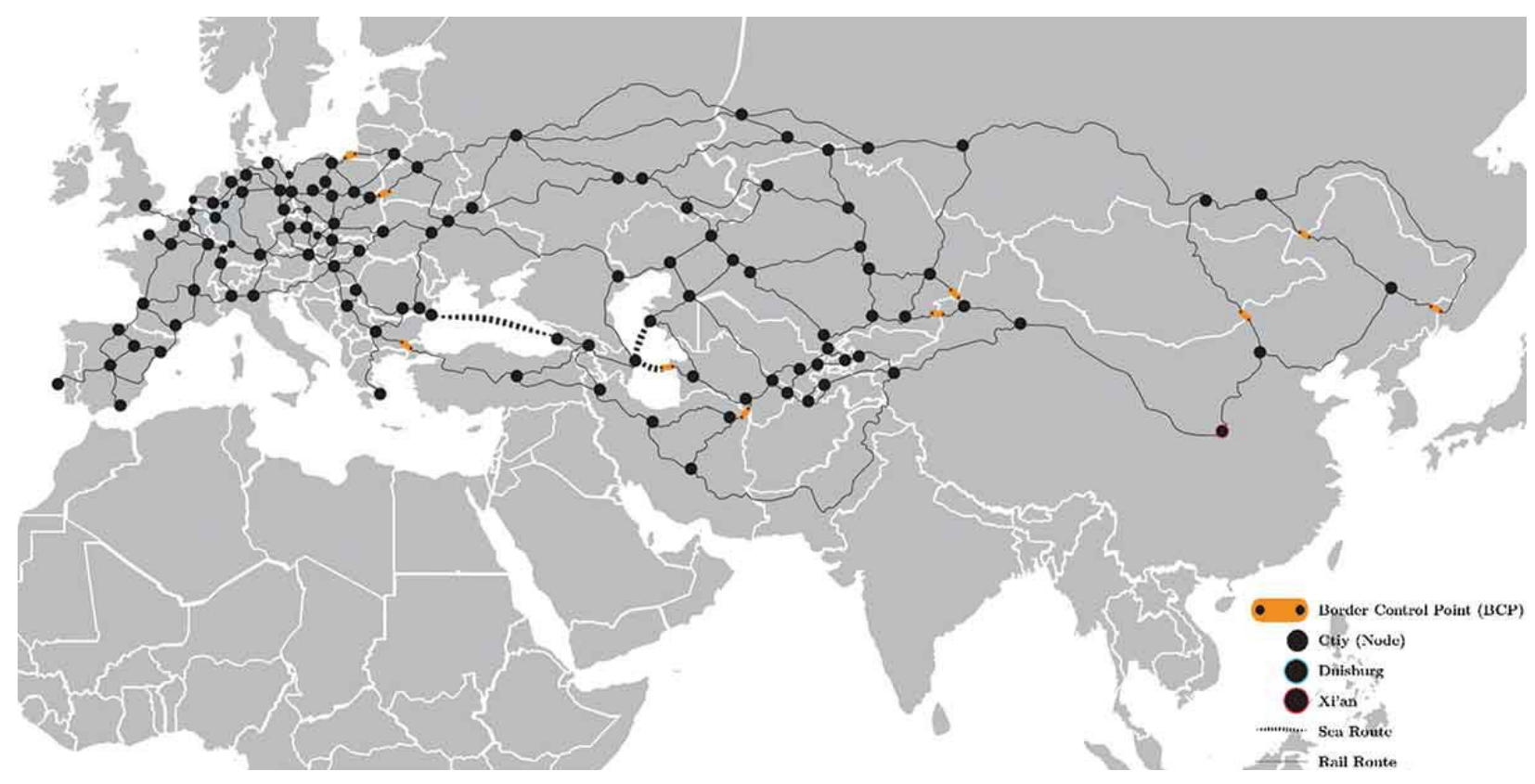

Figure 2. Key border control points of rail type from China to EU countries

Source: [7] 
aircraft, and maritime transport faced the problem of periodic restrictions on port operations).

Despite the chaotic environment and the resulting risks, the implementation of the BRI project, as mentioned above, is an important factor in the development of the world economy, and when planning investment vectors, one of the key tasks is to find constants in a chaotic environment that can serve as indicators of further development. Based on this assumption, in the development of logistics infrastructure, it is important to assess the prospects for certain investment decisions, taking into account the current logistics situation and, in particular, on the basis of the following indices:

1) $\mathrm{GCl}$ (Global Connectedness Index);

2) LPI (Logistics Performance Index);

3) AEMLI (Agility Emerging Markets Logistics Index);

Thus, according to DHL, which in the process of analyzing the Global Connectedness Index and taking into account data on trade, information flows, flows of people and goods, financial transactions, etc., revealed certain problems in the sustainability of international relations. Since the beginning of the pandemic, the above flows have decreased significantly. Nevertheless, a significant capacity for rapid recovery has also been identified, accompanied by an intensification of relevant flows in the second half of 2021. An important indicator of this index is that the level of global connectivity is much lower than society imagines. On the

Thus, with the insignificant level of global connectivity, the potential of the BRI project increases significantly, and on the other hand there is a question of increasing the level of global connectivity. This index is very useful in analyzing the development potential between countries on the route of goods from China to the EU. Because understanding the bottlenecks in the process of building transnational logistics corridors allows us to focus more effectively on the key success factors. In general, if we talk about the world picture, in Fig. 4 highlights the level of Global Connectedness Index, countries ranking map. In most of the countries through which the BRI rail routes pass, the level of Connectedness is below average, indicating the necessary vector of development of the project.

The Logistics Performance Index is one of the most revealing and specialized indices in the field of logistics development. Therefore, in determining the risks and potential of infrastructure changes, as well as the effect of their implementation, it is necessary to analyze in detail the results of the LPI ranking list of the relevant countries. The availability of data on six key indicators of the level of logistics organization in a given country allows to make a better focus on weaknesses and successfully position the strengths

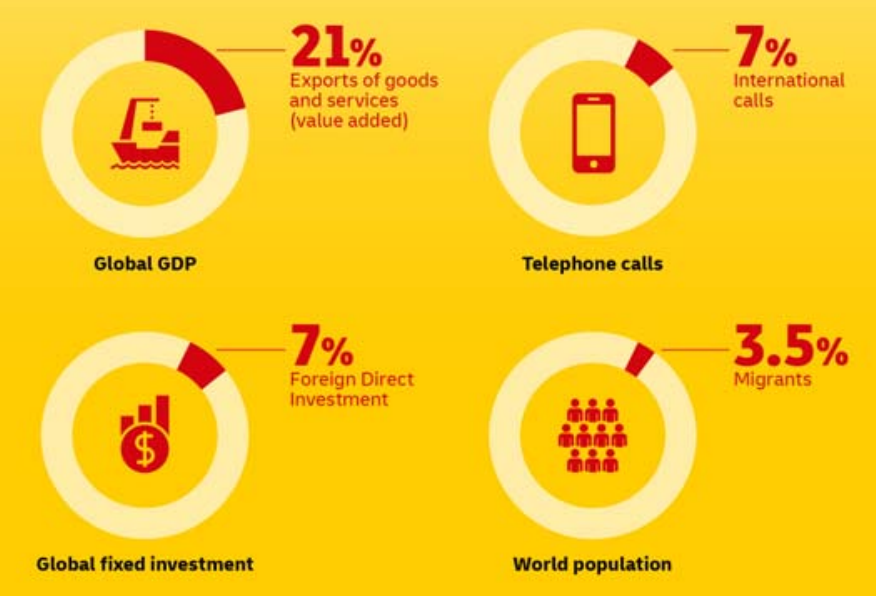

Figure 3. The level of global connectivity in terms of some sub-indicators

Source: [8; 9]

in the field of logistics. In the process of attracting investors, such data create prerequisites for the implementation of less risky projects, especially in conditions of uncertainty in international markets. The LPI index includes the following key indicators: (C) the efficiency of customs and border management clearance ("Customs"), (I) the quality of trade and transport infrastructure ("Infrastructure"), (E) the ease of arranging competitively priced shipments ("Ease of arranging shipments"), (Q) the competence and quality of logistics services - trucking, forwarding, and customs brokerage ("Quality of logistics services"), (T) the ability to track and trace consignments ("Tracking and tracing"), and (TM) the frequency with which shipments reach consignees within scheduled or expected delivery times (“Timeliness") [10].

Given that the BRI project takes place mainly within countries with developing economies, AEMLI data, in turn, also allows a detailed analysis of the potential opportunities and threats of certain projects in the analyzed countries. This index covers three key areas which are very meaningful for logistics market development:

1) Domestic Logistics Opportunities (covers information on the logistics market of the study region, the level of economy, population, level of urbanization and the presence of industrial clusters);

2) International Logistics Opportunities (covers data on the level of trade in logistics, the quality of infrastructure and the level of its connectivity, the level of customs efficiency (time, cost));

3) Business Fundamentals (provides information on the country's regulatory policy, the state's economy, in particular its budget, the state of corruption, the level of crime and the unemployment situation, the market's accessibility to investors, etc.).

The highlighted international indices do not provide a complete picture to evaluate an investment 


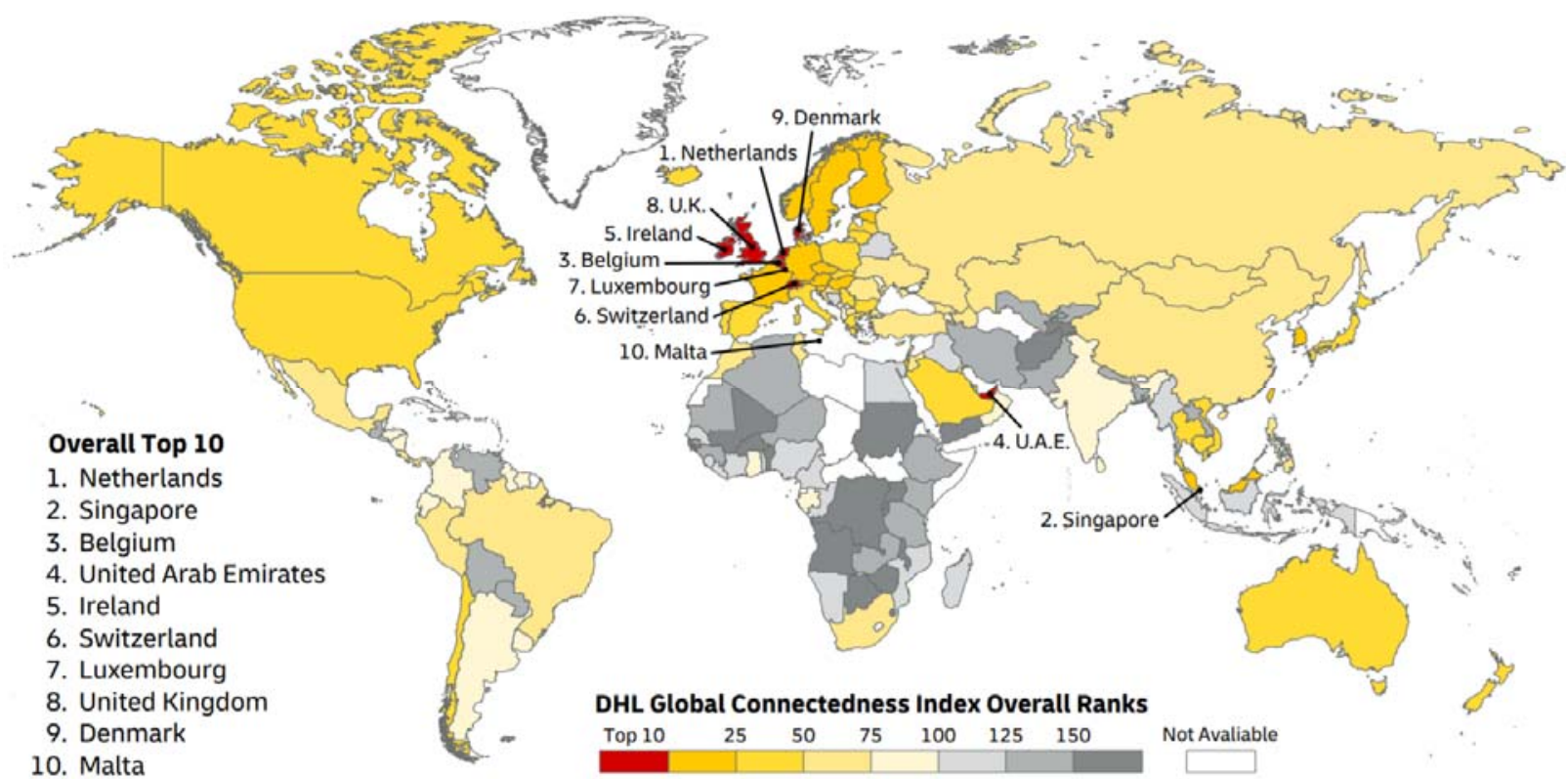

Figure 4. The Global Connectedness Index, countries ranking map, 2019

Source: [8; 9]

project, especially within the BRI, because its key feature is the potential in the synergy of infrastructure development. However, taking into account the relevant ratings for individual countries in which the BRI project is planned to be implemented will allow investors to form the right road map and avoid potential bottlenecks and risks in the realization of the investment project. It should also be noted that these indicators, despite their vector in the field of logistics, have a number of shortcomings, given which it is necessary to make appropriate strategic decisions. Especially, the LPI index is based on a survey of large companies that are mainly engaged in international activities. In such a situation, these estimates may have some distortion of the real situation in the country in terms of infrastructure in general and logistics. The AEMLI index, while assessing areas of logistics, mainly takes socio-economic data into account when ranking, which, in turn, should be taken into account when analyzing relevant indicators. In the context of the $\mathrm{GCl}$, the overall potential of trade, capital, information and people's movements by country is assessed to a greater extent. Conclusions about logistics can only be drawn on the basis of a derivative analysis of relevant indicators. Thus, taking these ratings into account is an important element of the $\mathrm{BRI}$ project planning process, but the relevant decisions cannot be based solely on them.

Conclusions. Factors that certainly affect the world situation: COVID-19, restrictions on the movement of people, the introduction of mass vaccinations and vaccination passports, restrictions on the operation of certain businesses depending on the epidemiological situation, the economy of countries on lockdown. Markets have changed, as have consumers. Projects that were in the BRI stage of implementation have undergone significant adjustments, while others have been suspended or closed. In this situation, further development of the BRI project is impossible without a detailed analysis of both the vectors of global economic development and the potential for infrastructure transformations at the local and global levels. According to the BRI Investment Report [11], between 2020 and 2021, the number of investments decreased significantly, the average deal size decreased, and most projects were revised to adapt to the new global situation.

The BRI project is an important initiative, and as the trend shows, especially in the post-Covid period, more and more attention will be focused on infrastructure development. Infrastructure and its strong sustainable capabilities, which give any country or project a significant competitive advantage in the long term, are now the most critical point in the decision-making process. New prerequisites for the implementation of BRI projects are: the search for optimal solutions based on a detailed analysis of the logistics infrastructure, a focus on financially viable initiatives, support for infrastructure initiatives of partner countries, increased international partnership, better analysis of projects, especially in terms of compliance with environmental requirements (SDGs).

\section{REFERENCES:}

1. Kirilieva A.V., Taraniuk L.M. (2019) Analiz lohistychnoho potentsialu Ukrainy $\mathrm{v}$ ramkakh kytaiskoi kontseptsii «Novoho shovkovoho shliakhu». [The analysis of the logistics potential of Ukraine in the framework of the Chinese concept "New Silk Road"]. Rozvytok mizhnarodnoi torhivli $v$ umovakh hlobalnykh 
ekonomichnykh dysbalansiv: materialy vystupiv Vseukrainskoho forumu z problem mizhnarodnykh ekonomichnykh vidnosyn (11 kvitnia 2019 roku). P. 119-121. Available at: https://conf.ztu.edu.ua/wp-content/uploads/2019/06/119.pdf (accessed 23 August 2021).

2. Hanusik A., Woźnica A. (2021) Strategic analysis for Poland as a European hub for Belt and Road Initiative. Journal of Economics and Management, vol. 43, pp. 94-113.

3. Ma W., Cao X., Li J. (2021) Impact of Logistics Development Level on International Trade in China: A Provincial Analysis. Sustainability, no. 13, p. 2107. Available at: https://www.researchgate.net/ publication/349354473_Impact_of_Logistics_Development_Level_on_International_Trade_in_China_A Proviñcial_An̄alysis (accessed $2 \overline{0}$ August 2021 ).

4. Gniēdziejko J., Rybiński Ł. (2021) Podlaskie Voivodeship as an Opportunity for the Development of the BRI in Europe. WSEAS Transactions on Business and Economics, vol. 18, pp. 338-344. Available at: https://www.researchgate.net/publication/348608013_ Podlaskie Voivodeship as an Opportunity for the Development_of the_BRI_in_Europe (accessed 25 August 2021).

5. Hing Kai Chan, Jing Dai, Xiaojun Wang, Lacka E. (2019) Logistics and supply chain innovation in the context of the Belt and Road Initiative (BRI). Transportation Research Part E Logistics and Transportation Review, no. 132(3), pp. 51-56.

6. Carlucci F., Corcione C., Mazzocchi P., Trincone B. (2021) The role of logistics in promoting Italian agribusiness: The Belt and Road Initiative case study. Land Use Policy, no. 108(2), p. 105560. Available at: https://www.researchgate.net/publication/351902327 The_role_of_logistics_in_promoting_Italian_agribusiness_The_Bëlt_and_Road_Initiative_case_study/citations (accessed 25 Aügust 2021).

7. Yilmaz Uygun, Jahanzeb Ahsan (2021) Analyzing the Railway Network of the Belt and Road Initiative. Cogent Business \& Management, 8:1, 1932066. Available at: https://www.tandfonline.com/doi/pdf/10. 1080/23311975.2021.1932066 (accessed 22 August 2021).

8. The DHL Global Connectedness Index (2020) Infographics: The world is far less globalized than many people think. Available at: https://www.dhl.com/content/ $\mathrm{dam} / \mathrm{dhl} /$ local/global/core/documents/info-graphics/g0core-pr-infographic-globalized-12032020.png (accessed 22 August 2021).

9. Steven A. Altman, Phillip Bastian (2020) DHL Global Connectedness Index 2020. The State of Globalization in a Distancing World. Available at: https://www.dhl.com/content/dam/dhl/global/dhl-spotlight/documents/pdf/spotlight-g04-global-connectednes s-index-2020.pdf (accessed 27 August 2021).

10. Urbanski S. (2014) Wildland fire emissions, carbon, and climate: Emission factors, Forest Ecology and Management 317:51-60. Available at: http://www.sciencedirect.com/science/article/pii/S037 8112713003447 (accessed 10 August 2021).

11. Nedopil Wang Ch. (2021) China Belt and Road Initiative (BRI) Investment Report H1 2021. Green BRI Center, International Institute of Green Finance (IIGF), Beijing. 24 p. Available at: https://green-bri.org/ wp-content/uploads/2021/07/21_07_22_BRI-Invest ment-Report-H1-2021.pdf (accessed 10 August 2021). 